\title{
Community Participation: Towards a safer housing environment
}

\author{
Hafazah Abdul Karim, Siti Mareenah Abdul Rashid \\ Faculty of Architecture, Planning and Surveying, \\ Universiti Teknologi MARA, Malaysia \\ drhafazah@gmail.com
}

\begin{abstract}
Lately crime rate in Malaysia has increased thus threatening the safety and security of the community especially those in high density areas. There are crimes that had targeted women and children and this had caused much stress to the urban residents. Human responses to these issues are to band together and take control of their environment and this is what happened to the residents in the PKNS flats in Taman Dato' Harun, Petaling Jaya. They wanted to build a close knit community that involve in community activities and at that same time this community will take care of each other's safety. This paper revolves around the participation of the residents in the PKNS flats in Taman Dato' Harun in Rukun Tetangga (RT) with the purpose to increase community involvement and interaction which will eventually lead to a more caring community. These flats have won the Petaling Jaya City Council Best Neighbourhood Contest in 2006 for its community activities. They consist of 300 housing units in five blocks of five storey flats. A sample of 30 percent (90 units) was taken by a stratified random sampling where every block and every level were accounted for. The data acquired was analysed using the SPSS programme. Findings showed that 100 percent of the respondents know their neighbours, 99 percent cooperate in community activities, 83 percent actively participated in RT, 85 percent of the respondent felt safe living in their flats, 72 percent felt that RT helped prevent crime and social misconduct. Other findings also showed that the community are very satisfied with the existence of the RT and felt that the activities have helped to foster positive community relations. This in turn decreases the perception of fear living in the urban area and instead gave the residents the perception of safety and well-being.
\end{abstract}

Keywords: safety, Rukun Tetangga, community activities, residents' participation.

eISSN 2514-751X @ 2017 The Authors. Published for AMER ABRA by e-International Publishing House, Ltd., UK.. This is an open access article under the CC BY-NC-ND license (http://creativecommons.org/licenses/by-ncnd/4.0/). Peer-review under responsibility of AMER (Association of Malaysian Environment-Behaviour Researchers), ABRA (Association of Behavioural Researchers on Asians) and cE-Bs (Centre for EnvironmentBehaviour Studies), Faculty of Architecture, Planning \& Surveying, Universiti Teknologi MARA, Malaysia.

https://doi.org/10.21834/aje-bs.v2i2.176 


\subsection{Introduction}

Life is full of challenges especially for people living in cities. The city is a place where people live, work and play in a dense environment with tall buildings, heterogeneous society and too many vehicles. In the city there are so many things to see, to hear, to capture, to absorb and the senses of the human being are over-stimulated. People go to work and go back home like clock work. The urban community is occupied with workrelated activities and the urban environment is especially catered for this. Everyday, urban people go out from their house to earn their living and in their busy schedule they may not be too concern with their social surroundings in their housing area. Many sociologists had studied the effects of the urban physical environment on the social surroundings of the housing environment and this paper will give a closer look into this matter.

\subsection{Literature Review}

\subsection{Theories of Urban Life}

One of the classical theories on community was written by Tönnies (1855-1937) a German sociologist who coined up the two famous concept; Gemeinschaft and Gesellschaft. He studied how life in the new industrial metropolis differed from life in traditional rural settings (Macionis 1999). Tönnies (1963; orig. 1887) referred to Gemeinschaft as a type of social organization by which people are bound closely together by kinship and tradition. On the other hand is a type of social organization by which people come together only on the basis of individual self-interest. According to Macionis, urban individuals are motivated by their own needs rather than a drive to enhance the well-being of everyone. From a certain perspective, urbanites display little sense of community and the erosion of close, enduring social relations but from another perspective urbanites might need to seek out the favours of others to fulfil the same collective needs. This may well be what Durkheim (1974; orig. 1924) was trying to explain on the character of urbanization that erodes mechanical solidarity yet at the same time generates a new type of bonding based on specialization and interdependence; which he termed as organic solidarity. The growth of industrial cities was thought to undermine tradition when sociologists saw that the urbanization offers more individual choice, moral tolerance and personal privacy. Yet these can be seen not as a loss but a gain for urban society. Another influential thinker of urban life is Louis Wirth (1897-1952) who defined the city as a large, dense and heterogeneous population. Wirth (1938) characterized the urban individual as impersonal, tolerant, secular and rational. The social relationships of the urbanites are formal and impersonal and that self-interest rather than friendship is the main reason for interaction. There are also many people in the city who take advantage of the anonymity of the urbanites and these people resort to immoral and illegal behaviours. Wirth also painted a gloomy picture of urban individuals who are alienated from the society and this resulted in depression and suicides. The sub-cultural 
theory by Fischer (1976) did not agree with Wirth on the lack of social well-being for the urban residents yet Fischer agreed that the city attracts a myriad of colourful social backgrounds including the deviant characters and behaviours. The dismal social environment in cities described by Wirth had challenged the urban planners to create residential designs that were thought to promote sense of community and social interaction between neighbours. This is such a simple way to solve a problem because as Talen (1999) argued 'the theoretical and empirical support for the notion that sense of community (particularly its affective dimensions) can be created via physical design factors is ambiguous at best'. Planners and designers should tone down their social determinism aspirations and declare that their designs are simply meeting the human requirements. Yet designs are in a sense important in promoting an environment conducive for community by providing suitable facilities in appropriate spaces.

\subsection{Man-Environment Relations}

Mackensen (1986) asserted that the quality of urban life depends heavily on the quality of social relations in neighbourhoods and also in the city, that is it influences the satisfaction with housing conditions; whereby Hafazah Abdul Karim (2008) found that residents in socially conducive environment in low cost housing were quite satisfied with their physical environment. Mackensen (1986) aptly explained that; 'the physical environment as part of the material setting people live in, is both a condition and a consequence of the pattern of the social relations in an area'. By 'condition' Mackensen (1986) said that it allows for social contacts, or makes them difficult sometimes even impossible. As a consequence, the physical environment is being shaped partly by the patterns of social relations, their content, intensity and frequency. The usage of urban spaces like a courtyard or urban parks reflects the activities or non-activities of the users; of their well-being or ill-feelings for example the acts of littering or the graffiti writings on walls.

Frick and Hoefert (1986) questioned the works of urban planners who presumably account for the "needs of users" in their design and apparently they did not because according to Rapoport (1986) there was no research. To correct this, urban planners have incorporated a vital stage in the design process; citizen's participation especially in developing the structure plan, the local plan and the action area plan.

The urban environment is like a magnet pulling all types of human activities including the negative and illegal activities. This has put a lot of stress on the urban community which developed into a type of fear known as fear of crime. Fear of crime, or its opposite, feelings of personal safety, is a dominant predictor of neighbourhood satisfaction (Taylor 1995). Perceived neighbourhood attributes such as friendliness of neighbours and safety have more effect of satisfaction compared to other background variables such as race, income and tenure (Spain,1988). An interesting finding from Parkes, Kearns and Atkinson (2002) showed that people living in the least affluent neighbourhood are more sensitive to crime as compared to the more affluent areas. It will be wrong to assume that there are more people living in the less affluent committing crimes compared to the more affluent areas but it is 
generally known that there are more crimes committed in the less affluent areas such as in the Black ghettos in the United States (Macionis 1999).

Talen (1999) asserted that environmental effects depended on particular social situations; the relationship between environment and behaviour is complex; and that the sense of community cannot be created through design but through certain individuals with a certain predisposition for social interaction and the need for the local community attachment.

\subsection{Safety Issues in Housing}

The quality of life for a community in an urban neighbourhood is very much affected with the absence of crime that largely influence the perception of safety and security and the absence of fear for the residents. Therefore it is important to improve the standards and the quality of the urban neighbourhoods in order to reduce the fear of crime. Quality of the local environment affects how safe residents feel and the neglect of local neighbourhoods invites anti-social behaviour and crime. People will avoid areas they feel are threatening thus causing fear of crime of an area to escalate (Brighton \& Hove 2005).

For decades sociologists have studied the phenomenon of crime and known that it is not evenly distributed across the urban landscape. Criminal behaviours which are considered deviant by the larger society like prostitution, juvenile delinquency, violent and property crime were found to be concentrated in the older and poorer sections of the city (Shwab 1992). Marginality and a lack of commitment to the goals and values of the larger society are characteristics of the population living in this type of area. This interpretation has been widely criticized because it is wrong to assume that being socially disadvantaged means being criminal but it has been found that people of lower social position commit more street crime than those with greater social privilege (Macionis 1999). Disparity of income is so great in cities and it is not surprising that Blau and Blau (1982) found that income inequality was far more sensitive indicator of urban crime than either race or poverty. They had concluded that cities with the greatest disparity between the rich and the poor were found to have the highest crime rate.

According to the Merriam-Webster Dictionary of Law (1996), a crime is an action or an instance of negligence that is deemed injurious to the public welfare or morals or to the interests of the state and that is legally prohibited. This word, in its most general signification, comprehends all offences but, in its limited sense, it is confined to felony. Other related acts include amongst others, acts of delinquency, evil-doing, illegal act, misconduct, a sinful act, a transgression, trespassing, viciousness, violation, and causing injury. Macionis (1999) defined crime as the violation of statutes enacted into criminal law by a locality, state or the federal government. There are two major types of crimes and they are (i) crimes against the person which constitute crimes that direct violence of the threat of violence against others and (ii) crimes against property which encompass crimes that involve theft of property belonging to others. 
Crime is a serious problem in cities all over the world. Urban violence generates a fear of crime. Crime and the fear of crime are serious threats to the stability and social climate of cities, to sustainable and economic development, the quality of life and human rights. Urban violence erodes the social capital of the poor. Insecurity affects the poor more intensely, breaks down socio-cultural bonds and prevents social mobility, thus contributing to the development of urban ghettos and stigmatized neighbourhoods (UN-Habitat 2006).

Brighton and Hove Crime and Disorder Reduction Partnership (2004) made a report on Community Safety, Crime \& Drugs Audit, identifies six problems which give rise to fear of crime; (i) people live in high crime area (ii) people have been a victim of crime (iii) people feel vulnerable (iv) people are poorly informed (v) people feel powerless and isolated (vi) people are subjected to persistent anti-social behaviour. In addition, it identifies two particular situations which can heighten fear of crime which are (i) poorly developed or maintained environment and (ii) public transport journeys and links between transport modes, especially the walking and waiting parts of journeys and travel at night. It can also inhibit people from addressing or challenging crime and anti-social behaviour within their communities.

\subsection{Safety in Residential Neighbourhoods: Malaysian Context}

The perception of well-being in housing are intertwined with the perception of satisfaction for safety of residents; indoor safety and outdoor safety. Safety issues in residential area are mainly focussing on the incidences of crime such as burglary, kidnapping, thefts and arson, apart from the issues of accidents resulting from road traffic or playground mishaps.

Table 1 will show the types of crimes and violence reported in Petaling Jaya from 2005 to 2008. These figures only show reported crimes and it is believed that there are many crimes that went unreported for various reasons. The police statistics show that there are a lot of criminal activities in the Petaling Jaya as a whole from snatch thefts to murder. The number of violent crimes in Petaling Jaya has increased from 2005 to 2008. These disturbing figures are very unsettling for the residents living in this area apart from the fact that the density of the people living in Petaling Jaya is high. The average density of population living in Petaling Jaya is 40.4 people per hectare but in some areas of Petaling Jaya especially in the southern part are 161.5 people per hectare. The high concentration of people has been known to promote social issues such as crime and social disorders. The figures in Table 1 are examples of the problems that exist in a populated area such as Petaling Jaya. 
Table 1: Crimes Statistic in Petaling Jaya (2005-2008)

\begin{tabular}{|c|c|c|c|c|c|c|c|c|}
\hline \multirow{2}{*}{ Types of crime } & \multicolumn{2}{|c|}{2005} & \multicolumn{2}{|c|}{2006} & \multicolumn{2}{|c|}{2007} & \multicolumn{2}{|c|}{2008} \\
\hline & $\mathrm{F}$ & $\%$ & $\mathrm{~F}$ & $\%$ & $\mathrm{~F}$ & $\%$ & $\mathrm{~F}$ & $\%$ \\
\hline \multicolumn{9}{|l|}{ A: Violent Crime } \\
\hline Murder & 14 & 0.2 & 18 & 0.5 & 24 & 0.5 & 27 & 0.5 \\
\hline Rape & 3 & 0.1 & 63 & 1.8 & 79 & 1.7 & 67 & 1.3 \\
\hline $\begin{array}{l}\text { Group Robbery with } \\
\text { Firearm }\end{array}$ & 165 & 2.8 & 2 & 0.1 & 17 & 0.4 & 18 & 0.3 \\
\hline $\begin{array}{l}\text { Group Robbery without } \\
\text { Firearm }\end{array}$ & 79 & 1.3 & 156 & 4.4 & 658 & 14.4 & 1606 & 31.0 \\
\hline Robbery with Firearm & 62 & 1.1 & 49 & 1.4 & 50 & 1.1 & 11 & 0.2 \\
\hline Caused Injury & 139 & 2.4 & 213 & 6.1 & 205 & 4.5 & 182 & 3.5 \\
\hline Total $(\mathrm{A})$ & 462 & 7.9 & 501 & 14.3 & 1033 & 22.6 & 1911 & 36.8 \\
\hline \multicolumn{9}{|l|}{ B: Property Crime } \\
\hline Day Housebreaking & 633 & 10.8 & 428 & 12.2 & 479 & 10.5 & 947 & 18.3 \\
\hline Night Housebreaking & 1875 & 32.0 & 630 & 17.9 & 855 & 18.7 & 770 & 14.8 \\
\hline Stolen Property & 354 & 6.0 & 1261 & 35.8 & 1754 & 38.4 & 1282 & 24.7 \\
\hline Snatch Theft & 2543 & 43.3 & 698 & 19.8 & 447 & 9.8 & 281 & 5.4 \\
\hline Total (B) & 5405 & 92.1 & 3017 & 85.7 & 3535 & 77.4 & 3280 & 63.2 \\
\hline Total $(A+B)$ & 5867 & 100.0 & 3518 & 100.0 & 4568 & 100.0 & 5191 & 100.0 \\
\hline
\end{tabular}

Note: F= Frequency

(Source: District Police Headquarters, Petaling Jaya, Selangor, 2009)

The statistics show that there are two types of crime that are on the rise; (i) group robbery without firearm and (ii) house breaking during the day. Criminals are getting bolder as they commit crimes in broad daylight and do not need any firearms to rob people. The rapid increase in population also increases the numbers of bad people in the cities which affect the well-being of the majority of the urban residents. This situation has been acknowledged by the police force whereby the concentration of people attracts social misfits and criminal activities. Due to this, local communities have decided to form resident associations or Rukun Tetangga to encourage neighbours participating in community activities promoting social integration and community awareness. 
Rukun Tetangga (RT) are generally neighbourhood associations that promote integration of residents working together towards the safety and harmony of residential areas. RT is a setup under the Department of National Integration and Unity and has its own website; www.jpnin.gov.my where Malaysians can easily accessed and peruse the requirements to form their own RT in their housing areas. The initial projects were launched in the early years of the 1970 s to help minimize the occurrence of crimes in residential areas. Until today,

$\mathrm{RT}$ is still prominently active in such areas where they run more fellowship programmes than night patrols. RT was previously very much associated with night patrols where groups of residents walk around every night in order to keep the area safe. Today, RT's role is more towards promoting neighbourliness than security. There are programmes like cooking classes, sewing and singing classes and such. RT's responsibilities and roles have decreased much since its inception but still have managed to bring residents together for a good cause.

The activities of RT within their neighbourhood include recreation, culture, finance, administration, welfare, social, education and security. Besides that, RT can identify and understand the problems faced by the community, helping in reducing the problems of that community. They can also carry out or create their own project venture to add to the community's financial resources. In addition, RT may also be the middle man between the community and the agencies, whether government agencies or private agencies in providing data or information about their area. Managing the complaints and problems of the inhabitants; enhancing and improving the cleanliness of their area are also part of the roles of RT.

\subsection{Methodology}

A study on the perception of safety and the participation of residents in community activities was carried out in the PKNS (Perbadanan Kemajuan Negeri Selangor) flats of Taman Dato' Harun in Petaling Jaya. Map 1 shows the study area marked in red.

The PKNS flats of Taman Dato' Harun was built in 1981 and comprises of 5 blocks of flats and each block has five floors with 12 units on each floor. There are a total of 300 units of houses which was initially built for MPPJ quarters but later became transit houses for a squatter resettlement project nearby. The 'transit' lasted about two years for one block and more than two years for the other four blocks. Each unit of two bedroom cost between $\mathrm{RM} 47,000$ to RM50,000. This costing is above the low cost unit price and therefore the unit is considered a medium cost apartment but at the lower end. 


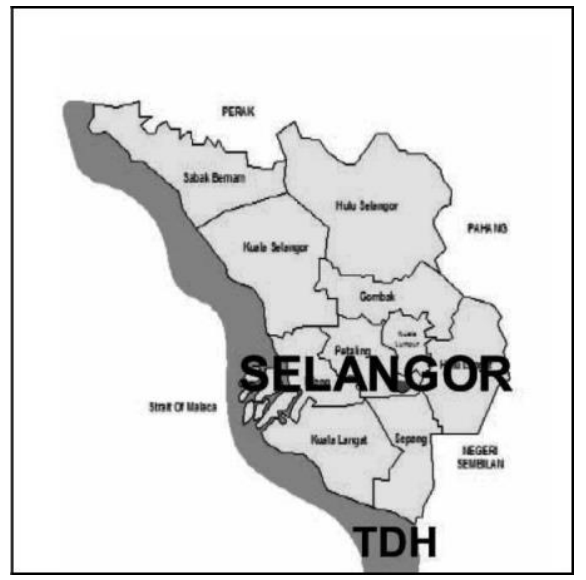

Figure 1: Taman Dato' Harun (TDH) in Petaling Jaya (source: Author, 2009)

There is a periphery of fences surrounding the five blocks of flats which give the housing area a sense of security. Inside the housing area, there are car parking spaces, a mosque, a playing court, one community hall, one meeting venue and green open spaces (Figure 2).

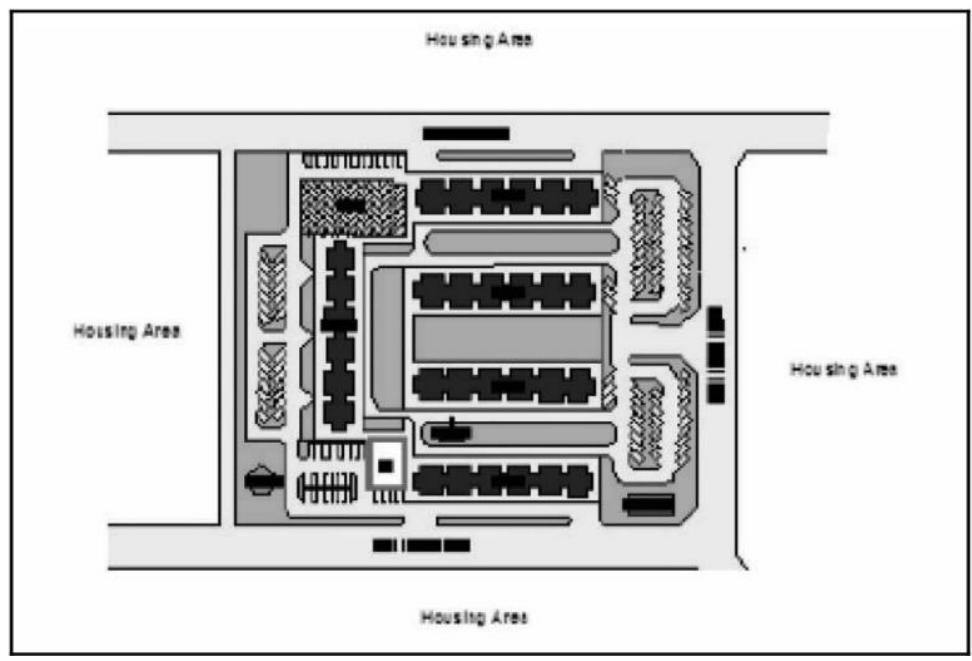

Figure 2: The site plan of the PKNS flat in Taman Dato' Harun,, Petaling Jaya. (source: Author, 2009) 
The residents of the study area had decided to form the KRT (Kejiranan Rukun Tetangga) which is the neighbourhood level RT; in 2001 spearheaded by Encik Ismail Latib, a teacher who took the initial effort in gathering and organizing the community. Actually there was an unwanted incident of racial clashes in 2001 in Petaling Jaya and this speeded the process of the formation of KRT. Apart from the main committee, KRT in the study area has subcommittees in charge of the women activities and the young residents' activities.

The social measures used in this study were based on these objectives; i) the activities conducted by the KRT, ii) the participation of the residents iii) the satisfaction towards the safety of the community in the housing area, and iv) the satisfaction towards the function of the KRT. Identifiable indicators such as the perception and opinions on safety, satisfaction, problems are measured through the Likert scale method where the lowest scale of 1 shows the most negative value and the highest scale of 5 shows the most positive value.

Methods used to acquire data were through observation during the field survey and the interview session using the questionnaire. The total number of respondents was 90 head of households which made up 30 percent of the total number of units. The number of sample from each block is from 17 percent to 22 percent. The respondents were selected through the stratified random sampling method and from each floor and each block to ensure equal representation.

\subsection{Discussion}

\subsection{Profile of Respondents}

The findings from the study showed that the largest percentage of respondents were between 41 to 50 years old (40\%). Age of residents is known to be an important factor in the characteristics of neighbourly resident (Parkes, Kearns and Atkinson 2002 and Groves et.al 2003). The largest percentage for education attainment for the residents is those with the secondary school certificate $(52.2 \%)$, the second is from the primary school leavers $(42.2 \%)$ and next are the Diploma and Degree holders (4.4\%). The types of occupation of the respondents are mostly in the manufacturing and services industry whereby 65.5 percent earned between RM1001 to RM2000. The high percentage of owners which is 79 percent with 73 percent of them staying more than 10 years is a good indication of a stable community (Parkes, Kearns and Atkinson 2002). More than 90 percent of the respondents are satisfied with their family's well-being in the aspects of economy, health, education, savings and household size.

\subsection{Perception of Safety}

Results showed that 100 percent of the respondents knew their neighbor living in the housing area; this condition is helpful in the cooperation between neighbours. Results also 
showed that 89 percent of respondents were satisfied with the cooperation and community activities and 79 percent satisfied with community relationships. The types of perception on safety in the community are shown in Table 2. Generally the majority of respondents felt safe living in their neighbourhood (86\%) and they seem to have adapted living in a crowded environment $(86 \%)$. The percentage of the respondents feeling safe from crime and other social misconduct are reduced slightly $(71 \%)$ while $(67 \%)$ felt secured living here.

Table 2: The perception of safety of respondents in study area in 2008

\begin{tabular}{|l|c|}
\hline Types of perception & $\%$ \\
\hline Generally feeling safe in the neighbourhood & 86 \\
\hline Feeling safe in a crowded environment & 86 \\
\hline Feeling safe from crime and other misconduct & 71 \\
\hline Feeling secured & 67 \\
\hline
\end{tabular}

\subsection{Existence of Crime and Social Problems in Study Area}

The respondents in the study area admitted that there were cases of criminal activities and social problems in the study area, before and after the setting up of the KRT, but the percentage has decreased after KRT was practiced. Table 3 showed a decrease of these activities according to the opinions of the respondents.

Table 3: The Percentage of Respondents Responding to the Existence of Crime and Social Problems Before and After the Setting Up of KRT

\begin{tabular}{|c|c|c|c|}
\hline \multirow{2}{*}{ Types of Crime and Social Problems } & \multirow{2}{*}{$\begin{array}{c}\text { Before } \\
\text { Yes }\end{array}$} & \multicolumn{2}{|c|}{ After } \\
\hline & & Less & None \\
\hline Theft & 88.9 & 83.3 & 16.6 \\
\hline Illegal racing (Rempit) & 55.6 & 46.7 & 53.3 \\
\hline Loitering & 48.9 & 32.2 & 67.7 \\
\hline Vandalism & 47.8 & 41.1 & 59 \\
\hline Truancy & 44.4 & 41.1 & 59 \\
\hline Drug Addicts & 38.9 & 25.6 & 74.4 \\
\hline Gangsterism & 18.9 & 15.6 & 84.4 \\
\hline
\end{tabular}




\begin{tabular}{|l|c|c|c||} 
Snatch theft & 4.4 & 4.4 & 95.6 \\
\hline House break-in & 3.3 & 3.3 & 96.7 \\
\hline Physical Assault & 1.1 & 1.1 & 98.9 \\
\hline \hline
\end{tabular}

Before the setting up of KRT, theft seems to be a problem with 89 percent of the respondents and other problems are illegal racing (56\%), loitering (49\%), vandalism (48\%), truancy (44\%), drug addicts (39\%) and others. After KRT was practiced, the occurrence of problems became less as seen in Table 2.

\subsection{Involvement of Respondents in KRT}

Findings show very encouraging participation by respondents whereby 99 percent of them cooperated in the community activities and 83 percent of respondents are active in KRT while the less active or inactive respondents made up of only 17 percent. The types of activities participated by the respondents are the Merdeka (Independence) month activities $(97 \%)$, gotong royong (neighbours get-together sharing of community work) for marriage and festival preparations (90\%), gotong royong for qurban (sacrifice of livestock during $\mathrm{Haj}$ celebrations) and aqiqah (sacrifice of livestock in commemoration of a child's birth) (89\%), variety games $(71 \%)$, visits and tours $(59 \%)$, meetings and cultural activities $(56 \%)$, community surveillance $(39 \%)$ and others. Respondents are very agreeable with KRT's activities whereby 72 percent felt that the activities are very encouraging towards community integration. Furthermore respondents felt that KRT has been very helpful $(72 \%)$ as an organized community association to prevent crime and other social misconduct.

\subsection{Best Neighbourhood Award 2006/2007}

The PKNS flats of Taman Dato' Harun has been awarded the Best Neighbourhood Award in 2007 by the Petaling Jaya City Council which won them RM50,000. The KRT has performed a great job in gathering the community of those flats to participate in its programs and has produced excellent results. Various activities were organized for all levels of the community from the young to the elderly, women and men including all races and religion. The activities not only promoted social interaction and community integration, they also generated extra income from the recycling program that collects unwanted and discarded items; and also from waste materials like newspapers, magazines, bottles and cans. Some of the recycled materials were creatively used in handicraft making classes that were attended by the residents. The KRT also has a community fruit and vegetable plots inside their housing area by optimizing the limited available open spaces. The KRT also has a business venture of renting out tents, chairs and tables for outdoor functions and the income contribute to the KRT's fund which can be used for the community's social functions, activities and welfare reasons. The Department of National Integration and Unity also gives a yearly allocation of RM4800 to the KRT in facilitating activities and programmes. The KRT has achieved the aspirations of the Department by successfully 
creating a sustainable community whereby the community takes care of the social wellbeing including the safety aspect of the residents

\section{0 Conclusion}

The human factor in an urban environment is very sensitive to the conditions of the physical environment. The housing area of the PKNS flats of Taman Dato' Harun, Petaling Jaya has many problems relating to crime and social problems. The data in Table 1 is evidence to the existing criminal activities and the rising problems of some of these crimes in Petaling Jaya. The data on perception of safety in 2008 showed that the majority of the residents generally felt safe even when living in a crowded housing area and the main reason for that are the existence of the KRT. The activities that they participate in make them know each other and integrate within the community; and this makes it easier to conduct a voluntary surveillance within the housing area. The KRT is an effective way to bring the residents together, exploiting the existing human capital in ways to create a safe and harmonious community in an urban physical environment.

\section{Acknowledgement}

This study was made possible by the continuous support from Universiti Teknologi MARA, Malaysia.

\section{References}

Blau, J. R. \& Blau, P.M. 1982. Metropolitan structure and violent crime. American Sociological Review. 47 : 114 128.

Brighton \& Hove. 2005. Safe in The City. http://www.safeinthecity.net/index.html [11 June

2006]

Brighton \& Hove. 2004. Drug and Alcohol Action Team. Communities Plan 2004-2006. http://www.safeinthecity.net/audit/17-physical-environment-and-quality-of-life.pdf [10 June 2006]

Durkheim, E. 1933. The division of labour in society. New York: Macmillan.

Fischer, C. 1976. The urban experience. New York: Harcourt Brace Jovanovitch.

Frick, D. (ed.) 1986. The quality of urban life: Social, Psychological and Physical Conditions. Berlin: Walter de Gruyter.

Frick, D. And H. Hoefert. 1986. 'Man-Environment Relations'. In Frick, D. (ed.) 1986. The quality of urban life: Social, Psychological and physical conditions. Berlin: Walter de Gruyter. Pp.151-157. 
Hafazah Abdul Karim (2008) The Quality Of Life of Residents in Urban Low Cost Flats in Klang And Shah Alam, Selangor, Malaysia. Unpublished Ph.D Thesis. Bangi: University Kebangsaan Malaysia.Mackensen, R. 1986. Social networks. In Dieter Frick. The quality of urban life. Pp. 49-60. New York: Walter De Gruyter. Pp. 49-53.

Macionis, J.J. 1999. Sociology. $7^{\text {th }}$ Edition. New Jersey: Prentice Hall.

Merriam-Webster's Dictionary of Law. 1996. Merriam -Webster Inc.http://dictionary. reference.com/browse/crime (15 August 2009)

Parkes, A., Kearns, A. and R. Atkinson. 2002. The Determinants of Neighbourhood. CNR (Centre for Neighbourhood Research) PAPER 1. http://www.bris.ac.uk/sps/ cnrpaperspdf/cnr1pap.pdf (7 July 2006)

Rapoport, A. 1986. The Use and Design of Open Spaces in Urban Neighbourhoods. In

Frick, D. (ed.) 1986. The quality if urban life: Social, Psychological and physical conditions. Berlin: Walter de Gruyter. Pp. 159-175.

Spain, D. 1988. The Effect of Changing Household Composition on Neighbourhood Satisfaction, Urban Affairs Quarterly, 23 (4). Pp. 581-600.

Schwab, W.A. 1992. The sociology of cities. Englewood Cliffs: New Jersey.

Talen, E. 1999. 'Sense of Community and Neighbourhood Form: An Assessment of the Social Doctrine of New Urbanism'. Urban Studies. Vol. 36, No. 8, pp.1361-1379.

Taylor, R.B. 1995. The Impact of Crime on Communities, Annals of the American of Political and Social Science. 539. pp. $28-45$.

Tönnies, F. 1955. Community and Society. New York: Harper and Row. (Original work published in 1887)

UN-HABITAT. 2006. Safer Cities Approach. http://www.unhabitat.org/programmes/ safercities/approach.asp [10 June 2006]

Wirth. L. 1938. 'Urbanism as a way of life' in American Journal of Sociology. 44, pp.1-24. 